\title{
Layer-by-Layer Assembled Microfiltration Membranes for Biomolecule Immobilization and Enzymatic Catalysis
}

\author{
V. Smuleac ${ }^{1,3}$, D. A. Butterfield ${ }^{2,3}$, D. Bhattacharyya ${ }^{1,3^{*}}$ \\ ${ }^{1}$ Department of Chemical and Materials Engineering, ${ }^{2}$ Department of \\ Chemistry, and ${ }^{3}$ Center of Membrane Sciences University of Kentucky, \\ Lexington, KY 40506
}

\section{Supplementary information:}

\section{Conditions for polyelectrolyte and protein attachments}

No salt or buffers were used in any experiments; the washing steps were carried out with deionized ultrafiltered water, at $\mathrm{pH} 5.8$, except for enzyme desorption performed using DIUF water at $\mathrm{pH} 3.5$.

The $\mathrm{pH}$ was adjusted according to the type of polyelectrolyte or protein used. Thus, for the covalent attachment of the first electrolyte layer, PLL or PLGA, the pH was above 9.1 where the terminal amine is deprotonated and suitable for the nucleophilic attack. The duration of the coupling was typically one hour, when $45 \mathrm{~mL}$ of the feed solution were passed twice through the membrane.

In the case of PSS and PAH electrostatic immobilization, the $\mathrm{pH}$ was kept between 6 and 6.5, where all polyelectrolytes are charged. Typically $100 \mathrm{~mL}$ solution was passed through the membrane for 1-1.5 hours.

The electrostatic immobilization of all biomolecules was performed at a $\mathrm{pH}$ range of 5.5-7. The covalent attachment for AP and GOx, was conducted at a pH of 9-9.5, where the amino acid residues are non charged and again capable of nucleophilic attack. This experiments consisted of passing $35 \mathrm{~mL}$ feed solution through the membrane for GOx, and $18 \mathrm{~mL}$ for $\mathrm{AP}$, respectively, and the duration was between 35 to $40 \mathrm{~min}$. 
The concentrations for the feed permeate and elution (wash) solutions for proteins and polyelectrolytes are presented in Table 1S. The inlet (feed) and outlet (permeate) substrate concentrations during catalytic reactions, are presented in Table $2 \mathrm{~S}$.

BABA (biotinylated amido benzoic acid) analysis was performed by permeating a feed solution through the membrane. Permeate samples were periodically analyzed. This gives the breakthrough curves; initially the permeate concentration is lower than the feed concentration and as sorption proceeds the sites are saturated. At this point the permeate concentration approaches the initial feed concentration. For a membrane without avidin, no BABA sorption was detectable. Typical breakthrough curves, expressed as the normalized concentration vs volume passed through the membrane are presented in Figure 1S.

In order to verify whether the multilayer assembly has a significant role on enzyme immobilization (amount immobilized, activity), a controlled experiment using a single layer was performed. Figure $2 \mathrm{~S}$ shows the rate of $\mathrm{H}_{2} \mathrm{O}_{2}$ formation at a constant substrate concentration. It can be observed that after only eight cycles, the rate of product formation is decreased to $50 \%$ of the original value. Since this rate is expressed as mmol product/(min mg enzyme), this decrease was attributed to enzyme leaching and not deactivation. That is due to the fact that on a similar system (enzyme immobilized on three layer assembly), such a decrease was not observed. The initial $\mathrm{H}_{2} \mathrm{O}_{2}$ formation rate with single layer assembly was about $20 \%$ lower than that observed with the multi layer system. The stability upon immobilization constitutes a major advantage for the multilayer system. 
Table S1. Typical polyelectrolyte and protein concentrations during immobilization steps

\begin{tabular}{|c|c|c|c|}
\hline Species & Feed conc. $(\mathrm{mg} / \mathrm{L})$ & Permeate conc. $(\mathrm{mg} / \mathrm{L})$ & Washed conc. $(\mathrm{mg} / \mathrm{L})$ \\
\hline $\mathrm{PLL}^{\mathrm{a}}$ & 318.7 & 283.4 & 13.0 \\
\hline $\mathrm{PSS}^{\mathrm{a}}$ & 306.2 & 285.6 & 13.8 \\
\hline $\mathrm{PAH}^{\mathrm{a}}$ & 112.4 & 99.7 & 0.8 \\
\hline PLGA $^{b}$ & 221.7 & 174.2 & 5.2 \\
\hline $\mathrm{PAH}^{\mathrm{b}}$ & 102.3 & 83.5 & 2.6 \\
\hline $\mathrm{PSS}^{\mathrm{b}}$ & 360.8 & 311.0 & 18 \\
\hline Avidin $\mathrm{pH} 8^{\mathrm{b}}$ & 11.5 & 0 & 0 \\
\hline $\mathrm{pH} 5.7^{\mathrm{b}}$ & 13.5 & 7.9 & 4.5 \\
\hline BSA pH $6.2^{b}$ & 15.8 & 15.4 & 3.2 \\
\hline $\mathrm{pH} 3.5^{\mathrm{b}}$ & 14.3 & 3.6 & 0 \\
\hline GOx $1^{\text {st }}$ & 14.5 & 4.7 & 0 \\
\hline $2^{\text {nd }}$ & 22.1 & 2.0 & 0 \\
\hline $\begin{array}{c}\text { Both are "a" } \\
\text { membranes } \\
\text { operated at pH } \\
7.0\end{array}$ & & & \\
\hline $\mathrm{AP} \mathrm{pH} 6.5^{\mathrm{a}}$ & 12.3 & 5.4 & 0 \\
\hline
\end{tabular}

${ }^{a}$-PLL-PSS-PAH membrane

b-PLGA-PAH-PSS membrane 
Table 2S. The inlet and membrane outlet concentrations in the catalytic reactions

\begin{tabular}{|c|c|c|}
\hline Substrate & $\begin{array}{c}\text { Inlet substrate concentration } \\
(\mathrm{mM})\end{array}$ & $\begin{array}{c}\text { Outlet product } \\
\text { concentration }(\mathrm{mM}) \text { at } \\
\text { various times }\end{array}$ \\
\hline Glucose & 2.5 & 0.074 \\
& & 0.194 \\
& 7 & 0.279 \\
\hline & & 0.241 \\
& 10 & 0.426 \\
& & 0.626 \\
\hline $\mathrm{pNPP}$ & 25 & 0.383 \\
& & 0.691 \\
& & 0.844 \\
\hline & 0.05 & 0.612 \\
& & 0.924 \\
& & $0.002(5 \mathrm{~min})$ \\
& 0.1 & $0.004(7.5 \mathrm{~min})$ \\
& & $0.005(10 \mathrm{~min})$ \\
\hline & 0.25 & $0.003(5 \mathrm{~min})$ \\
& & $0.009(10 \mathrm{~min})$ \\
\hline & 0.5 & $0.003(5 \mathrm{~min})$ \\
& & $0.014(7.5 \mathrm{~min})$ \\
& & $0.017(10 \mathrm{~min})$ \\
\hline & & $0.005(5 \mathrm{~min})$ \\
& & $0.024(7.5 \mathrm{~min})$ \\
& & \\
\hline & & $0.031(10 \mathrm{~min})$ \\
\hline
\end{tabular}

* For glucose runs (water saturated with oxygen) samples were taken every one min analyzed for $\mathrm{H}_{2} \mathrm{O}_{2}$, average permeate water flux $=15 \times 10^{-4} \mathrm{~cm} / \mathrm{s}$; for pNPP samples were taken every 2.5 to $5 \mathrm{~min}$ and analyzed for p-nitrophenol, average permeate water flux $=5 \times 10^{-4} \mathrm{~cm} / \mathrm{s}$ 


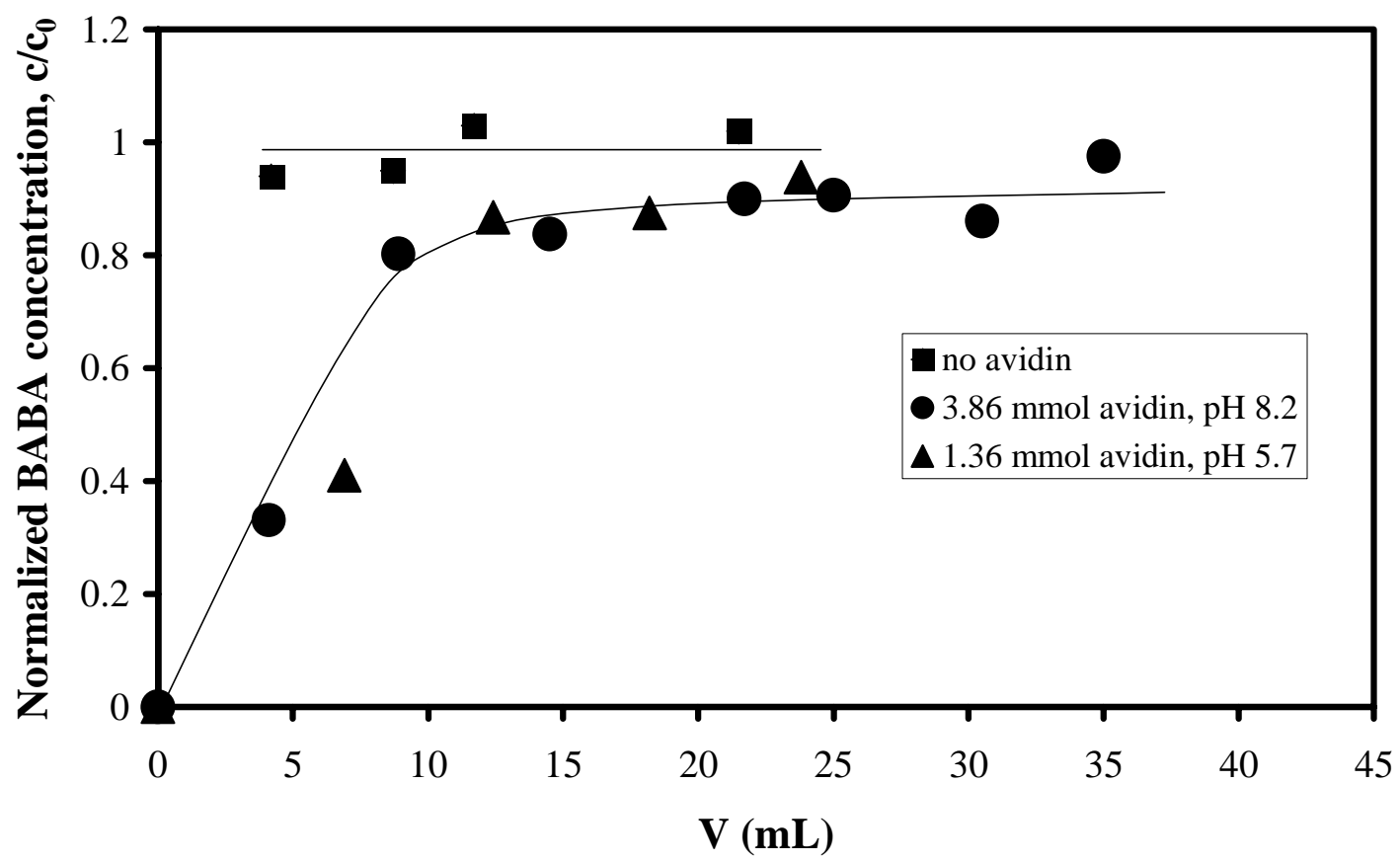

Fig. 1S. Breakthrough curves for BABA pick up on Nylon membrane (PLGA-PAH-PSS layer) 


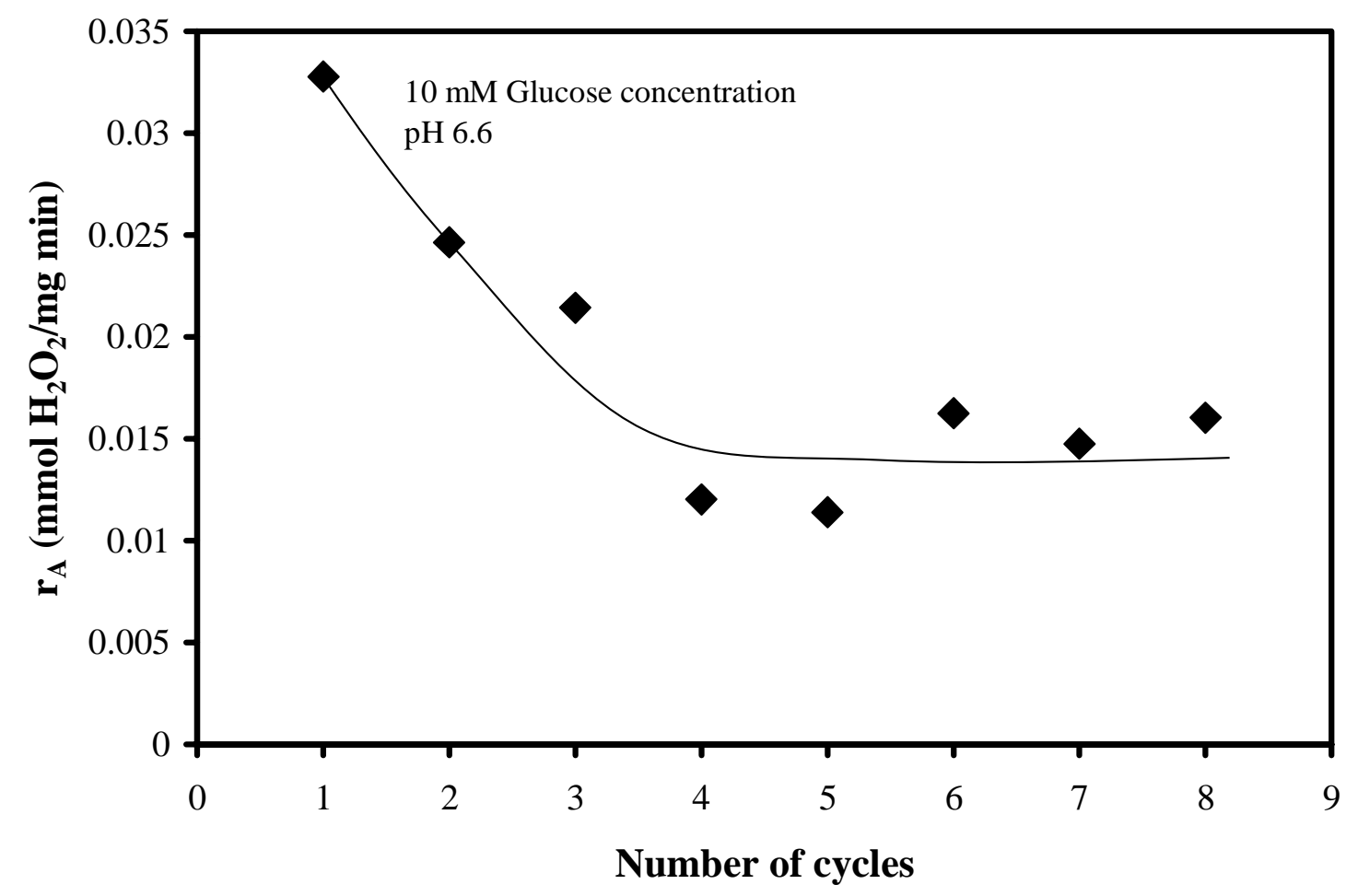

Fig. 2S. Rate of product formation as a function of the number of cycles, at a constant substrate concentration (for single layer polyelectrolyte system) 